\title{
SOBRE JUAN BAUTISTA MAÍNO
}

\author{
POR \\ ALFONSO E. PÉREZ SÁNCHEZ \\ Universidad Complutense
}

This article published new documents about the activity of the Domenican painter Juan Bautista Maino specially concerning his concept of the practice of Painting in relation to the other arts. Works hitherto unknown are publised here for the first time. Also illustrated are portraits of the Conde de Añover de Tajo and his wife, whose collections were, in addition given valuation by the artist.

La importancia, significación y belleza de la obra de Juan Bautista Maíno, sin duda la personalidad más fuerte y atractiva entre los artistas que trabajaban en Madrid a la llegada de Velázquez, obliga a conceder especialísima atención a cuantas noticias nuevas puedan añadirse a su todavía demasiado escueta biografía y al reducido catálogo de su producción ${ }^{1}$.

La singularidad de su arte, tan directamente vinculado a las experiencias romanas de los primeros años del siglo, por su conocimiento del caravaggismo "claro" y su sentido de la naturaleza y el paisaje, tan ligado al mundo romano de Eshheimer y Anibale Carracci, le confieren un puesto de primerísimo orden entre los artistas de su tiempo. Su condición de monje y hombre de letras, unido al prestigio de su posición de profesor del rey Felipe IV cuando príncipe, le convirtieron, sin duda, en figura influyente en el ambiente cortesano. $\mathrm{Y}$ seguramente fue artista más solicitado y activo de lo que las palabras de Palomino permitieron suponer.

Conviene reconsiderar algunas noticias dispersas que se han dado a conocer en los últimos años, con aportaciones importantes en ocasiones -aunque en otras sean más discutibles-, y presentar otras enteramente nuevas, que ayuden a perfilar personalidad tan apasionante, en el el doble aspecto de enriquecer su catálogo, dando pistas para la identificación de obras nuevas, y pro-

1 Sobre Maíno se ha publicado recientemente en Italia, "fuori comercio», un libro con pretensiones de monografía: María Consuelo Boitani, Juan Bautista Maíno. Relazione sulla vita, le opere i miracoli compiuti in pittura da un «lucidisimo ingenio" e su coloro che ne hanno scritto, Roma-Fratelli Palombi Editori, 1995. Se trata de un modesto trabajo de recopilación de noticias y referencias bibliográficas, sin crítica alguna, que toma como punto de partida el volumen de AnguloPérez Sánchez, Pintura madrileña del primer tercio del siglo XVII, Madrid, 1969, transcribiendo por entero cuanto allí se cita abreviadamente, y reproduciendo no sólo las obras seguras sino también todo lo que ya había sido eliminado razonablemente de su catálogo, e incorporando algunas otras obras atribuidas sin crítica, e inaceptables en su mayoría. 
curando penetrar un poco en su pensamiento y en la conciencia que de su propio arte pudiese tener ${ }^{2}$.

Muy recientemente ${ }^{3}$ se ha dado noticia de unas obras suyas poseídas por el canónigo de Granada Don Juan de Matute, que las registra en su memoria-inventario, redactada apresuradamente en Madrid en ocasión de la grave enfermedad que le llevó a la tumba el 8 de enero de 1629. El canónigo, que había visitado Italia y había mantenido contacto con el duque de Osuna, virrey de Nápoles entre 1616 y 1620 como es sabido, estaba bien informado de la personalidad de Maíno, de quien poseía "un quadro entero de la Magdalena en el desierto", que califica "de muy alta pintura», que obliga a pensar en algo próximo a la bella imagen que conserva el Prado procedente el retablo de las Cuatro Pascuas" 4.

Al mencionar al pintor, le dice «de la orden de Sto. Domingo, que de pintor, es y ha sido maestro de pintar de Su Magd.», y añade una expresión un tanto confusa que obliga a pensar poseyese otro lienzo del mismo maestro: «este cuadro [la Magdalena] y el de Santa María la Mayor son de su mano». En el mismo inventario se recogen, en primer lugar, dos imágenes de devoción, un «berdadero retrato de Nuestra Señora del Pópulo de Roma, grande con su cornisa ngra dorada en partes" y otro "retrato de la Virgen, de soberana pintura, de nuestra señora Santa María la Mayor, con su cornisa dorada en partes».

Como ha sugerido Barrio Moya al publicar el documento, es probable que esa Virgen fuese obra del pintor durante su estancia romana, y quizás prototipo de otras imágenes devocionales salidas luego de su obrador conventual, pues la imagen gozó de popularidad en España.

En el mismo año en que el Canónigo granadino deja constancia de su estima por el monje dominico, se inauguraba en la Sala capitular del Convento de Atocha el altar de Santo Domingo en Soriano, pintado por Maíno e inspirado en una estampa traída de Italia por un fraile que, tras una grave enfermedad, fue a Soriano en peregrinación de gracias. El prior madrileño, Fray Francisco de Sotomayor, quiso sirviese de modelo para un lienzo, ya que el corregidor de la Villa y Ayuda de Cámara del Rey, no quiso autorizar el culto de la estampa, sin duda por fidelidad a las normas de Trento sobre las imágenes «no usadas».

El dominico Padre Manuel María de los Hoyos, al dar a conocer un abundante material his-

\footnotetext{
2 Especialmente interesante es el artículo de Mina Gregori "Un' inédita 'Adorazione dei Pastori' di Juan Bautista Maíno» en los Scritti di storia dell'arte in onore di Federico Zeci, Tomo II, Milán, 1984, pp. 615-618, con reflexiones perfectamente válidas sobre su formación italiana. El breve artículo de Steven N. Orso "Why Maíno? A note on the Recovery of Bahía" publicado en Source. Notes in the History or Art, vol. X, n. ${ }^{\circ}$ 2, Winter, 1991, pp. 26-31, no es sino una ligera -y gratuita- reflexión sobre la posible conexión conceptual entre los lienzos de Santo Domingo en Soriano del pintor dominico y el lienzo de la Recuperación de Bahía donde, como en aquellos, se presenta un lienzo a la veneración de un monje y de unos súbditos, respectivamente. Un artículo de J. José Junquera y otros de Barrio Moya, con documentos de tasaciones y la presencia de algunas obras de Maíno en inventarios del seiscientos, se comentan más abajo. Más importancia pretende el de Gianni Papi «Proposte per Juan Bautista Maíno» en Studi di Storia dell'Arte, 3, Todi, 1993, donde se insiste en el componente savoldesco de Maíno, común a Francesco Buoneri, el "Cecco de Caravaggio", al que seguramente conocería, y se le atribuyen algunas obras, a mi juicio de modo nada convincente.

Notables son las aportaciones documentales de M. Agulló, especialmente la que precisa la condición de «maestro de pintura del Príncipe nuestro señor» (el futuro Felipe IV) en 1619 y atestigua en viaje del pintor a Lisboa (M. Agulló, Documentos para la historia de la pintura española, I, Madrid, Museo del Prado, 1994, p. 65), aclarando además, de modo definitivo, la personalidad de su madre, que no es la Ana de Castro que supuso F. Cortijo Ayuso («El pintor Juan Bautista Maíno y su familia", Wad-al-Hayara, n. ${ }^{\circ}$ 5, 1978), sino una dama portuguesa como ya había probado Fernando Marías ("Juan Bautista Maíno y su familia», A.E.A., 1976, pp. 468-470).

3 J. Luis Barrio Moya, "La colección pictórica de Don Juan de Matute, canónigo de la Catedral de Granada (1628)" en Revista del Centro de Estudios Históricos de Granada y su Reino, n. ${ }^{5}$, Segunda Época, Granada, 1991.

4 Sobre el retablo toledano de las Cuatro Pascuas, bien conocido de antiguo como su obra más significativa, véase: Juan Miguel Serrera, "Juan Bautista Maíno: Notas sobre el retablo de las Cuatro Pascuas», Boletín del Museo del Prado, 1989, Vol. X, pp. 35-41, donde, documentalmente incorpora la Magdalena y el San Antón, compañeros, al retablo, tal como ya habíamos intuido D. Diego Angulo y yo en 1969. La Magdalena se reprodujo en el citado libro de Angulo-Pérez Sánchez, 1969, lám. 261 y se expuso en Sevilla Caravaggio y el naturalismo español, 1973, n. 73.
} 
tórico inédito de su orden, proporciona datos curiosos sobre la historia y el motivo por el cual se realizó el lienzo, y los milagros y prodigios que se sucedieron en la ocasión, sirviéndose adẹmás de la Historia del Monasterio de Santo Tomás escrita por el P. Antonio Martín Escudero y publicada parcialmente en 19005 .

La estampa que sirvió de modelo, como ya indiqué en otro lugar ${ }^{6}$, ha de ser la que, sin indicación de autor, se conserva hoy en la Cívica Racolta de Stampe Bertarelli, en el castillo Sforcesco de Milán, que ahora reproducimos. Maíno supo transformarla sutilmente, manteniendo todos los elementos de la composición, invirtiéndola y dotándola de su personalísimo sello en los tipos humanos. Perdido el lienzo original en el incendio de Atocha según el testimonio de Jusepe Martínez, conocemos varias repeticiones autógrafas con escasas variantes - las más significativas en el rostro del monje que recibe el retrato de manos de la Virgen, sin duda buscando un cierto realismo de retrato en cada caso-, que atestiguan su éxito ${ }^{7}$ (Figs.1, 2 y 3).

Pocos años después, el 26 de abril de 1632, Maíno figura como tasador de las pinturas del fallecido Conde de Añover de Tajo, D. Luis Lasso de la Vega ${ }^{8}$, noble toledano retratado por Bartolomé González en un excelente lienzo fechado en 1619 que conserva la parroquial de Cuerva, junto al de su mujer Doña María Pacheco, firmado, sin fecha, por Rodrigo Villandrando (Figs. 4 y 5). Sè trataba de pocas pinturas y casi todas de carácter devocional, entre las que sólo destaca una Oración del Huerto, "copia de Luquetto", es decir de Luca Cambiaso, cuyo original debía, sin duda, conocer el padre Maíno.

Esa actividad de tasador, tan habitual entre los pintores del momento, podría quizás sorprender en un monje ligado, además, a la vida palaciega, pero no es única.

El 30 de enero de 1636, cuando acaba de realizar la pintura del salón de Reinos y se halla en su absoluta plenitud, consta otra vez su labor de tasador, en este caso con las pinturas de Don Francisco Díaz Romero, del Consejo de Su Majestad y su Alcade de Casa Y Corte, colección discreta, con algunas piezas tasadas en elevado precio, pero sin que se indique ni un solo nombre de autor ${ }^{9}$.

El propietario debía tener alguna relación con los dominicos, pues sorprende encontrar en la colección "un retrato de la Madre Agueda de la Cruz», personaje muy significativo de la vida devota madrileña, fallecida en Madrid el 20 de abril de 1621. Nacida en Aranzueque, fue Beata en Santo Domingo de Alcalá y se la tuvo en opinión de Santa ${ }^{10}$. Es posible que el retrato fuese obra del propio Maíno, tan ligado a ese mundo de devociones y arrebatos seudomísticos, como atestigua el conocido proceso de Isabel de Briñas ${ }^{11}$.

5 Fray Manuel María de los Hoyos, Registro Documental, T. III, Material inédito dominicano español, Valladolid, 1963, pp. 332-334

6 "Fray Juan Bautista Maíno, pintor dominico", Arte Cristiana, 764-765 (1994), pp. 433-442. El texto se leyó como comunicación en un congreso sobre "La vocación artística de los religiosos», celebrado en la Universidad Católica de Milán en 1994.

7 A las versiones citadas por Angulo-Pérez Sánchez, 1969, láms. 264 y 265, ha de añadirse el pequeño cobre del Museo Granet de Aix-en-Provence, que reprodujo Gianni Papi (art. cit., fig. 13) y mencioné yo mismo en el artículo citado en la nota anterior, así como la que guarda la National Gallery of Ireland en Dublín (Rosemarie Mulcahy: Spanish Paintings in the National Gallery of Ireland, Dublín, 1988, p. 31), atribuida a José Leonardo, aunque señalando su dependencia del modelo de Maíno.

8 José Luis Barrio Moya, «El pintor alcarreño Juan Bautista Maíno tasador de la colección pictórica del conde de Añover (1632)", Wad-al-Hayara, n. ${ }^{\circ} 17,1990$, pp. 345-352.

9 M. Agulló y Teresa Baratech Zalama, Documentos para la Historia de la Pintura Española, II, Madrid, Museo del Prado, 1996, p. 64.

${ }_{10}$ Las noticias sobre la beata las transmitió el Padre Martínez Escudero y se recogen en el citado Registro Documental del Padre Manuel M. ${ }^{a}$ de los Hoyos, 1966, p. 332.

11 Juan Pérez de Guzmán y Gallo, «En un proceso de la Inquisición de Toledo», Arte Español, 1914, pp. 55 y ss. 


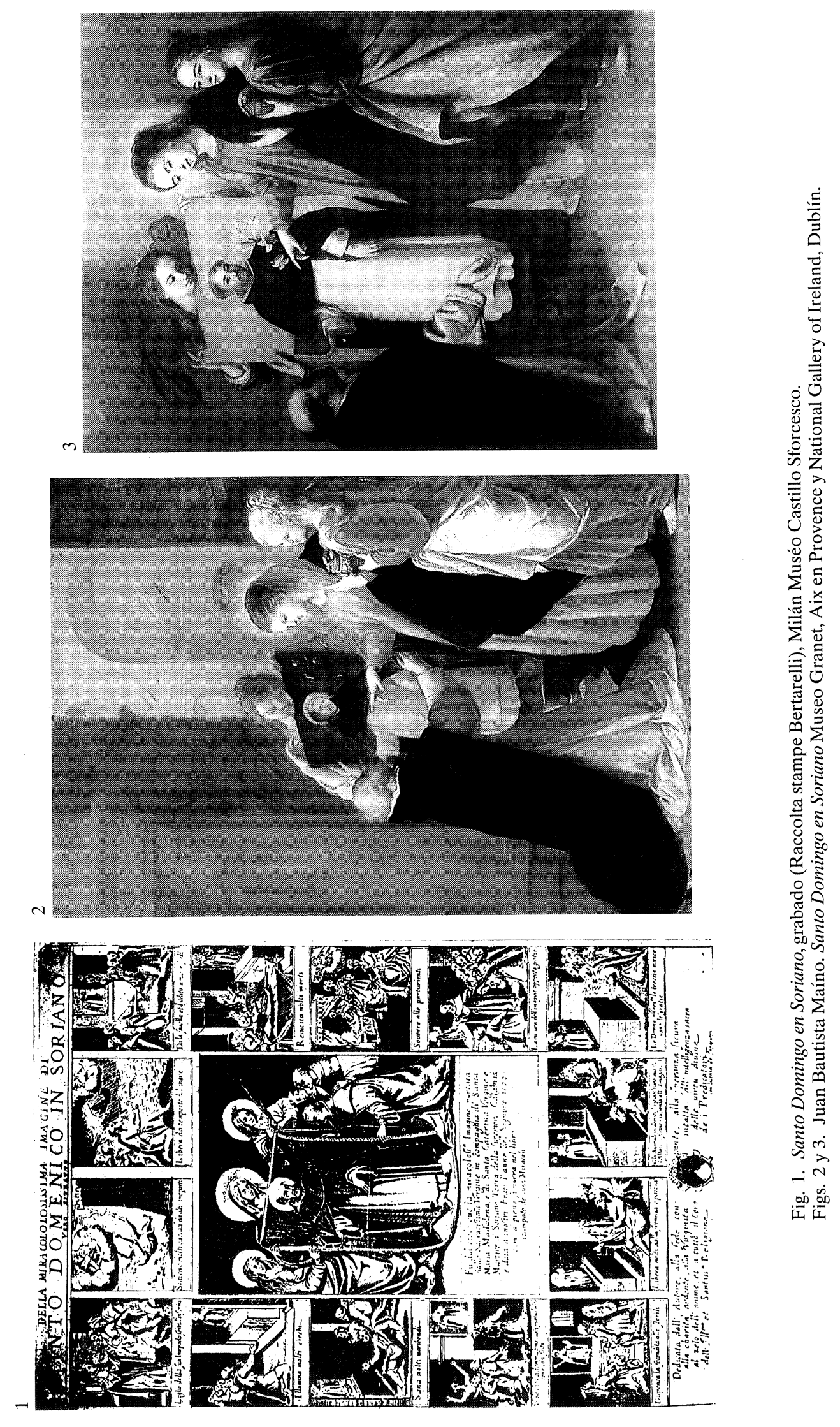


Siete días después de finalizada aquella tasación, se compromete a realizar un retable para la capilla que el Conde de Castrillo tenía en el convento de Espeja, en tierra de Burgos.

Gracias a la generosidad de Fernando Bouza, que me advirtió de la existencia de los documentos, y a la amable atención de Jesús Urrea y Belén Bartolomé que los han hecho copiar para mí en el archivo abulense del Conde de Orgaz, puedo presentar el curioso contrato que especifica detalladamente el contenido del retablo, por desgracia perdido, o al menos no identificado en ninguno de sus componentes.

El texto del documento del contrato es el siguiente ${ }^{12}$ :

«Digo yo Fr. Ju. Bapt ${ }^{\mathrm{a}}$ Mayno de la orden de $\mathrm{St}^{\circ}$ Domingo que por mandado y orden del Sr. conde de Castrillo Presidente del $\mathrm{C}^{\mathrm{o}}$ de Indias me encargo de pintarle seis cuadros que han de servir en un retablo que hace su $\mathrm{Ex}^{\mathrm{a}}$ en una capilla suya en el convento ---- de que es patrón, de los cuales seis cuadros tengo las medidas que dio el arquitecto ensamblador que hace el retablo y es así observaré en la conformidad que lo dice el arquitecto y cumpliré en los demás requisitos de esta obra conforme a lo que $\mathrm{S}$. Ex ${ }^{\mathrm{a}}$ me ha encargado. Es a saber que los cuatro de estos cuadros que son mayores, han de ser de las cuatro fiestas principales de la Virgen Ntra. Sra. en esta forma:

El primero de los dos de abajo que esta al lado del Evangelio sea la Natividad de Ntra. Sra. y el de el lado de la Epístola la Anunciación. De los dos altos el del Evangelio la Visitación y el otro la Asunción. Los dos más pequeños que están al lado de la custodia serán dos $\mathrm{h}^{\mathrm{a}} \mathrm{s}$ del testamento viejo que corresponden y son figuras del Santísimo Sacramento. La una del Maná en el desierto; la otra cuando Melquisedec, sacerdote y rey ofreció a Habraham pan y vino o la Cena legal de Cristo Ntro. Sr. a beneplácito de S. Exc ${ }^{a}$, los cuales cuadros me obligo a hacer y acabar para el día de San Juan de este presente año, mas o menos sin faltar en esto ni en nada de los requisitos pertenecientes al cumplimiento de este encargo y en particular en la verdad de la pintura en la disposición de las $h^{a} s$ que seran con todo el decoro que se requiere en cosas tan santas y con todo el estudio y diligencia que cabe en mi caudal y entendimiento con los adornos de colores los mas electos y costosos que se pueden hallar y usar sin ahorrar trabajo o costa alguna en la ejecución de todo lo dicho y todos los seis cuadros con sus lienzos sin costuras y en la forma dicha me obligo a hacer y acabar por el precio de 600 ducados que S.Exa mandará se me den a su disposición y gusto. Así mientras se hiciesen como después de hechos dichos cuadros y por ser así verdad lo firmé en seis de febrero de 1636 años.

Fray J ${ }^{\circ}$ Bapt $^{\mathrm{a}}$ Mayno"

Como puede verse, el pintor se acomoda a las dimensiones del retablo que le han sido facilitadas -y que ignoramos, pero que no debían ser excesivas, pues se trataba de un retablo de capilla-, y en cuanto a la iconografía se ciñe también a lo que el comitente le ha encargado.

Tiene cierto interés ver ratificada por un teólogo $-\mathrm{o}$ al menos por un hombre de iglesiaalgo que la observación de los retablos marianos y la lectura de los sermonarios permitía afirmar.

Junto a las "cuatro pascuas" (Natividad, Reyes, Resurección y Pentecostés), fiestas mayores de Cristo, el uso consagraba, paralelamente, otras cuatro fiestas principales de signo mariano (Natividad de la Virgen, Anunciación, Visitación y Asunción. En la predela, a los lados del sagrario («la custodia») irían, como es frecuente, temas eucarísticos "del testamento viejo» que corresponden y son figuras del Santísimo Sacramento. Es curioso que si bien el Maná parece absolutamente irreempazable, se ofrezcan dos opciones para la otra escena: Abraham y Melquisedec o La cena legal de Cristo, que podría pensarse fuese la Santa Cena, no precisamente del Testamento viejo.

12 Archivo del Conde de Orgaz, Ávila. Leg. XVII/41. "Cédula del P. fray Juan Bapt ${ }^{\mathrm{a}}$ Mayno en que se obliga a hacer las pinturas para el retablo de Espeja». 


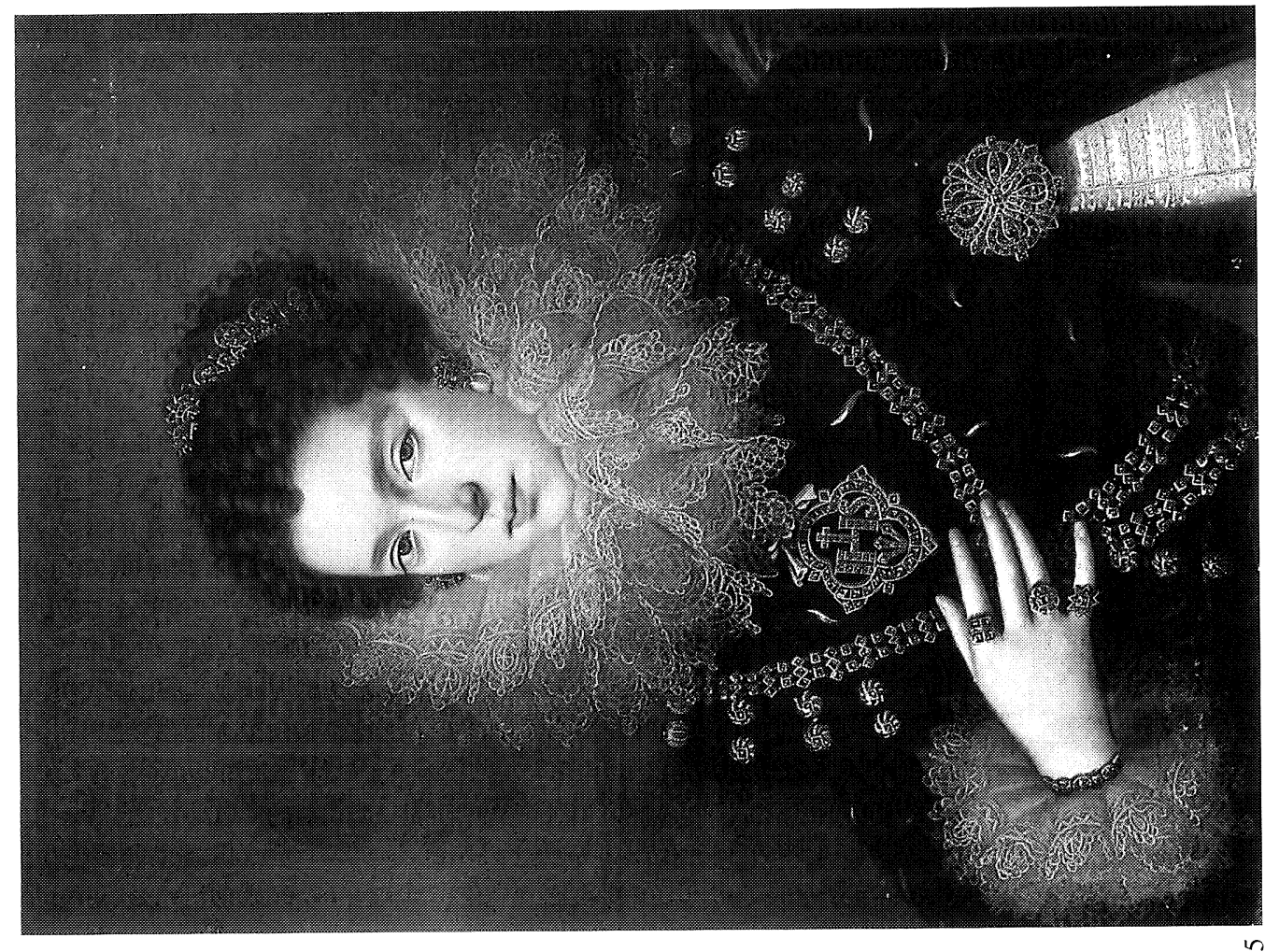

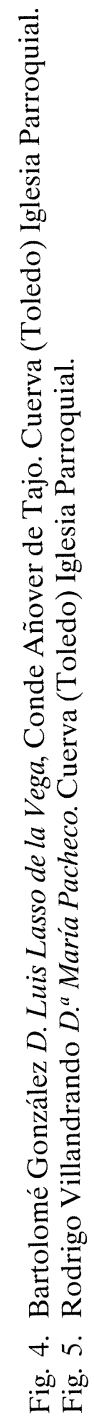


Se tratará, seguramente, de la Cena legal de los Hebreos (no de Cristo), que sí es tema bíblico frecuentemente utilizado como prefiguración eucarística. Recuérdense, por ejemplo, las pinturas de Tibaldi en el Sagrario de El Escorial.

Como buen y obediente seguidor de Trento, y preocupado por la ortodoxia y las intenciones morales del concilio, Maíno se compromete formalmente a "la verdad de las pinturas en la disposición de las historias", que: «serán con todo el decoro que se requiere en cosas tan santas" y a la vez, se esforzará en que los aspectos materiales sean también de absoluta calidad, «con todo el estudio y diligencia que cabe en mi caudal y entendimiento», con los mejores y más costosos colores y en lienzos sin costuras.

El precio de 600 ducados (6.600 reales), ciertamente alto, lo percibió en diferentes plazos, según se acredita en otro documento del mismo archivo, que asegura igualmente, la realización de las pinturas y su aceptación a plena conformidad ${ }^{13}$ :

«El P. Fr. Juan bautista Mayno. Cuenta de las pinturas que se obligó de hacer para el retablo de San $\mathrm{G}^{\circ}$ de espeja en que se concertaron y como se le ha dado satisfación.

Hazese cargo el Padre Juan bautista mayno de la orden de Santo Dom ${ }^{\circ}$ de 6.600 rs. en q se concertaron algunas pinturas q de orden del conde mi señor se obligo de hacer para el retablo del convento de San Gerónimo despexa de que se le da satisfación en la forma siguiente por averlas cactado.

Data

En 6 de febrero de 1636 libro el conde mi sr. al Padre fr. Juan Bautista Mayno 1000 rs. de von q valen $34.000 \mathrm{mr}$. en diego de bergara mas de obras pias del co de las Indias de la disposicion del conde mi sr. se le pagaran.

En 8 de julio de 1626 libro asimismo mi señor al dho Padre en dhas obras pias 2.200 rs. que valen 74.800 de vellon q recibio de di $^{\circ}$ berg $^{\circ}$.

En 16 de noviembre de 1636 libró el conde mi sr. al P. fr. Juan bautista Maino 1.200rs. de vellon q valen 74.800 que se le entregaron.

Por manera q data de esta cuenta 6.600 rs. de $v^{0} n$ con los q iguala con el cargo y no ay al tiempo contra ninguna de las partes y por qto el dho Juan Baut ${ }^{\mathrm{a}}$ ha entregado las pinturas conforme era obligado queda de acuerdo.

No hay alcance»

Lo que no podemos saber es si, en su entrega, se cumplió puntualmente el plazo estipulado, que cumplía el 24 de junio de 1636, o si hubo algún retraso en ella. Como puede verse, los pagos se escalonan hasta marzo de 1637 , pero es posible que ese retraso no sea señal de incumplimiento, pues el propio documento afirma que el pintor «ha entregado las pinturas conforme era obligado".

De muy otro interés son ciertas noticias que nos hablan de sus opiniones sobre el arte que practicaba y sus relaciones con otros oficios.

En 1620, en ocasión del pleito promovido por los pintores contra la pretensión de los doradores de erigirse en colegio y dar ordenanzas y nombrar veedores de oficio, Maino -que vive en el Colegio de Atocha- comparece como testigo por parte de los pintores, defendiendo que el oficio de dorador no tiene "de ninguna manera atributo de arte ni estudio alguno» ${ }^{14}$.

Aunque sus respuestas se ciñen muy fielmente al tono y redacción de las preguntas planteadas por los abogados de los pintores, que defienden la libertad de dorar, estofar y encarnar, sin someterse a examen alguno, y responden como es fácil suponer, a una mera cuestión de intere-

3 Idem. Leg. XVII/41.

14 Dio noticias de este pleito, I. Cadiñanos Bardeci, «Los Maestros Doradores madrileños y sus ordenanzas», Anales del Instituto de Estudios Madrileños, Tomo XXIV, 1987, pp. 239 y ss., pero no transcribió las importantes declaraciones de los testigos. Debo a Rocío Bruquetas la cuidadosa transcripción de los mismos que aquí se utiliza. La documentación procede del Archivo Histórico Nacional, Sección Consejos, Leg. 24.783. 
ses gremiales, el testimonio del pintor ofrece alguna luz, aunque muy reducida, sobre su visión de la pintura como arte y de su dignidad.

De sus palabras se deduce una sencilla visión de su arte, entendido, al menos en esta ocasión, como una práctica alejada de especulaciones teóricas. Sorprende un tanto, si se tiene en cuenta la tradición zucaresca viva en el Madrid de su tiempo por obra de Carducho -a quien sin duda conocía bien-, el hecho de que subordine el dibujo a la pintura, en contra de la vieja afirmación de que aquel es base y fundamento de las tres nobles artes. Maíno se atiene a la práctica división de la pintura en dibujo y colorido, a diferencia de Gómez de Mora, testigo también en el mismo pleito, que al hablar de los distintos géneros de pintura, insiste en que son "todo una misma cosa, nacidas de un principio, el cual se funda en el dibujo como la principal parte de la pintura» mostrando así una más rica educación teórica.

Sus palabras, en respuesta a la pregunta séptima en la que se demandaba si el arte de la pintura es superior al del dorado, son claras y tajantes:

"A la setima pregunta dijo que el arte de la Pintura es la raiz y el tronco de otros muchos ejercicios que della se derivan como es el dibujo, el colorido, la iluminación, el gastar el oro, el encarnar imágenes y el hacer grutescos, y cualquier otro género de distribución de colores, siendo así que el que es dueño de la pintura, como lo es del todo, lo será de las partes referidas concernientes a la Pintura, y que esas partes inferiores reconocen a la Pintura como su cabeza superior. Sabelo este testigo como persona que tiene ciencia y experiencia dello y saber y entender la dicha pinturan.

Y como respuesta a la novena pregunta, en la que se demanda si el arte de la pintura se compone de muchas partes dice:

"que si bien en sus nombres y ocasiones son distintos, es todo una misma cosa" precisando "que el arte de la Pintura se compone de varias cosas y las más propias son las que se han de hacer y ejecutar con el pincel como instrumento inmediato del arte de la pintura, como son paises y hacer retratos, historias, iluminaciones, encarnaciones de imágenes, grutescos sobre oro u otra cualquier materia, y así mismo dorar y hacer brocados y otros géneros de Pintura en oro o en cualquier otro material, que aunque se dice por diferentes nombres y en si son partes diferentes, todos se reducen a una mesma esencia que es la pintura. Sabelo este testigo práctica y teoricamente».

Su buen sentido y su evidente conocimiento de la realidad le hacen advertir bien la intención que se oculta tras el deseo de establecer ordenanzas y exámenes por parte de los doradores pues

«le parece que han querido algunos particulares doradores reducir el dicho oficio a pocas personas para hacer y deshacer los precios a su albedrío en daño del común, con algún género de sujección en los demás que ejercen el oficio del dorado».

Es cierto que las alegaciones de los pintores incluyeron en las preguntas a que habían de contestar los testigos términos análogos y en ocasiones casi literales, que facilitaban las respuestas convenientes a su defensa, pero Maíno las hace suyas con una evidente sobriedad y elegancia.

Es posible que el dominico ciñese sus respuestas a lo que constituye la razón del pleito, y no quisiese entrar en disquisiciones teóricas, pero lo cierto es que la visión del arte de pintar que manifiesta, es enteramente práctica y despegada de cualquier carga especulativa, que asoma sin embargo, como hemos indicado, en la declaración de Gómez de Mora, e incluso en la de Vicente Carducho, donde se define a los pintores como "personas científicas" que lo que ordenan lo hacen «debajo de preceptos y arte que como tales saben por haberlos estudiado».

En cuanto a obras conservadas y estudiables, es poco lo que puede añadirse de nuevo, pero sí deben señalarse algunas precisiones a las ya publicadas, que faciliten su mejor conocimiento.

Como novedad absoluta, vale la pena reproducir un pequeño cobre de dimensiones $0,20 \times$ 0,15 , que se encuentra integrado en su lujoso marco de fines del siglo x́xIII, que acoge otras pin- 


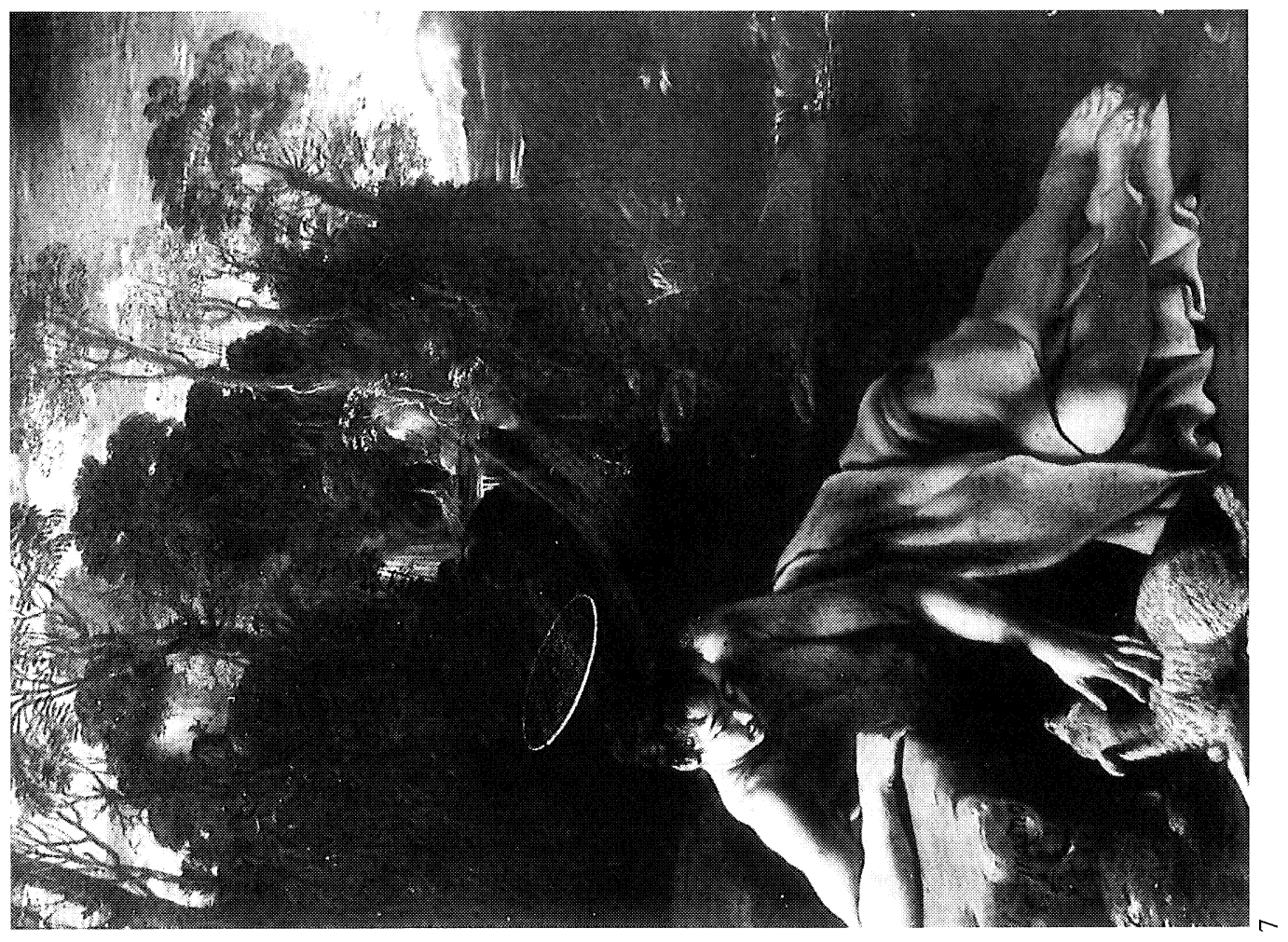

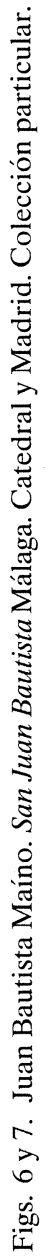

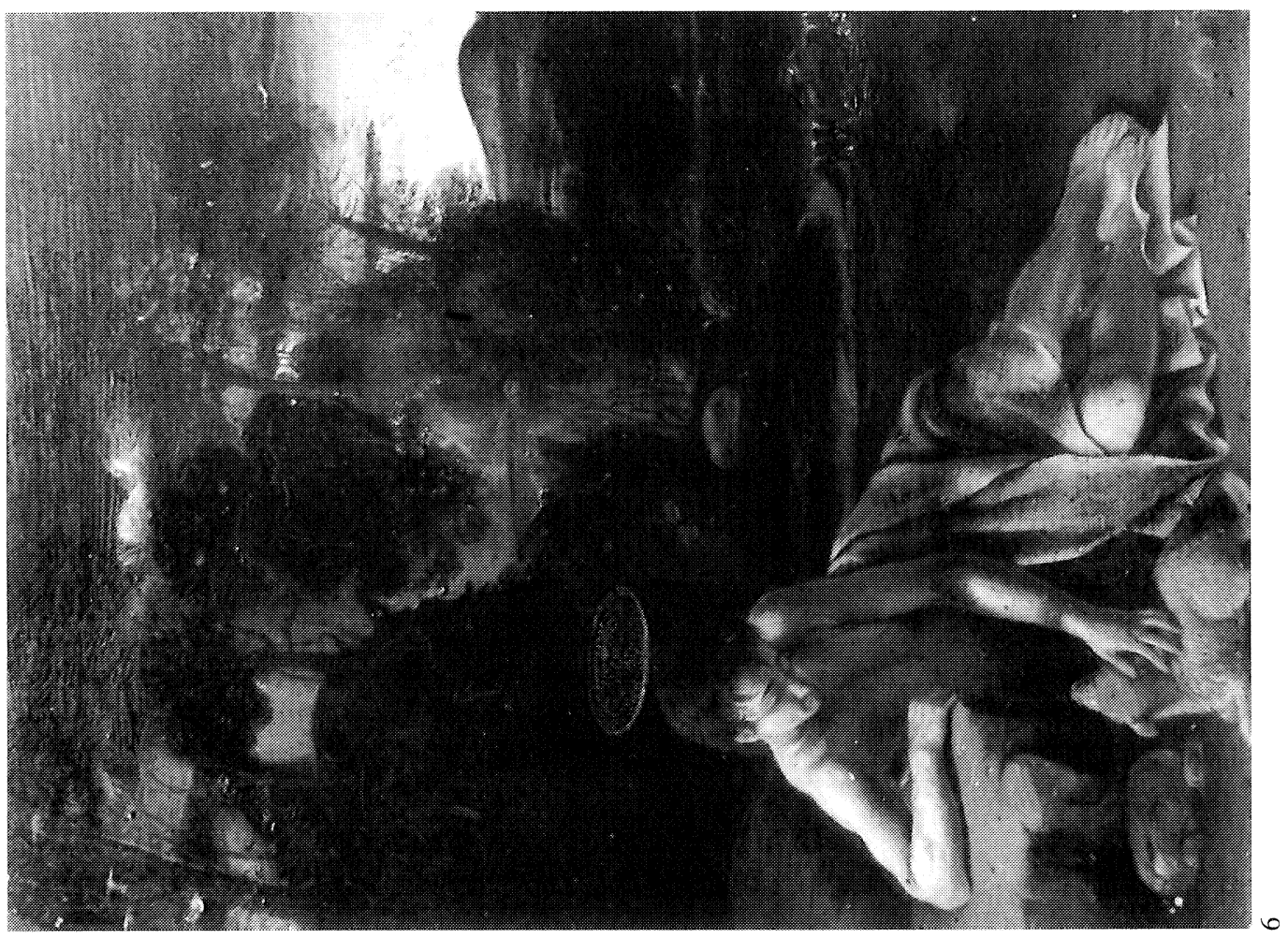


turas en la Catedral de Málaga. Se trata de un San Juan Bautista en el desierto, que repite, con ligeras variantes en el paisaje, el que en 1935 dio a conocer E. Harris ${ }^{15}$ como perteneciente a una colección particular madrileña y hoy en paradero desconocido. (figs. 6 y 7).

Como en éste, Maíno muestra aquí su perfecto conocimiento del paisaje italiano de los años iniciales del siglo, con muy especial interés por el mundo de Elsheimer y Anibal Carracci. La sensación umbrosa, el vibrante deslizarse del agua en las cascadas de la derecha, y el paso de la luz entre las ramas, sirven de fondo a la delicada figura de santo adolescente, que recostado junto a la fuente, acaricia el cordero, que alza hacia él el hocico húmedo. La luz, muy intensa sobre la figura del Santo, modela sólidamente las formas y la túnica roja se ciñe a los característicos pliegues blandos de perfil ondulante.

Corrobora esta nueva obra la dedicación del pintor a este género de pintura, de pequeño formato y refinadísima ejecución, de que hay otros ejemplos y de las que, seguramente aún será posible idenficar otras más. Ya Jusepe Martínez se refirió -y E. Harris lo subrayó a su tiempo-, a sus «figuras medianas de lindo gusto y perfección» ${ }^{16}$ y Lázaro Díaz del Valle insistió también en que Maíno fue "singular para las láminas» ${ }^{17}$.

Sobre cobre pintó también la interesante Conversión de San Pablo que dio a conocer Serrera ${ }^{18}$, la delicada Virgen de Belén que fue de las Mercedarias de Fuentes de Andalucía ${ }^{19}$ y el citado ejemplar del Santo Domingo en Soriano del Museo Granet de Aix.

Todas estas obras, de delicadísimo tratamiento y peculiar técnica, evocan, necesariamente, su formación romana. Allí hubo de familiarizarse con el soporte de lámina de cobre que por los mismos años utilizaban, con semejante primor, Anibal Carracci, Guido Reni y Domenichino, así como Arpino o Saraceni.

En España, en general, este soporte se usa para obras de carácter mucho más modesto.

En 1977, Juan José Junquera ${ }^{20}$, dio a conocer el importante retablo de la Trinidad del convento de Franciscanas de Pastrana (Guadalajara), obra indudable de Maíno que, tras unas accidentadas visicitudes del convento, abandonado recientemente por las escasas monjas que en él quedaban, ha pasado al Prado para su restauración, mientras se decide su emplazamiento definitivo.

Esta circunstancia ha facilitado su examen atento, y la obtención de excelentes fotografías, que merecen desde luego darse a conocer, permitiendo además, hacer algunas precisiones respecto a su fecha, que Junquera, remitiéndose a imprecisas referencias del convento, situaba en 1604. (figs. 8 y 9 ).

El propio crítico señalaba ya las semejanzas, en tipos y técnica, con las pinturas de San Pedro Mártir de Toledo, que se fechan con precisión entre 1612 y 1614. El examen directo, tras la restauración, obliga a situar el retablo de Pastrana en fecha muy próxima a ellas, especialmente las figuras de los ángeles niños que son muy semejantes a las del fresco del sotocoro del convento toledano y como ellas, muy cercanas a modelos del joven Reni y de Saraceni.

La opulencia de las telas -de ricos bordados en el Dios Padre y en el ángel de la derecha-, sólo hallan su equivalencia en las del Aarón del mismo fresco, cuyo rostro, como ya señaló Junquera, se repite en el Dios Padre del lienzo de Pastrana, y la corona de cabezas de querubines

15 E. Harris, "Aportaciones para el estudio de Juan Bautista Maíno», en Revista Española de Arte, 1935, pp. 333-339.

16 Jusepe Martínez, Discursos practicables del nobilísimo arte de la Pintura, ed. 1866, p. 121.

17 Lázaro Díaz del Valle, en Sánchez Cantón, Fuentes literarias para la historia del arte español, Vol. II, 1933 , p. 349.

18 Juan Miguel Serrera, "Juan Bautista Maíno. Notas sobre el retablo de las Cuatro Pascuas", Boletín del Museo del Prado, Vol. X, 1989, pp. 40-41.

19 Angulo-Pérez Sánchez, Pintura madrileña, 1969, p. 312, n. ${ }^{\circ} 20$, lám. 259.

20 J. José Junquera, “Un retablo de Maíno en Pastrana», Archivo Español de Arte, 1977, pp. 129-140. 

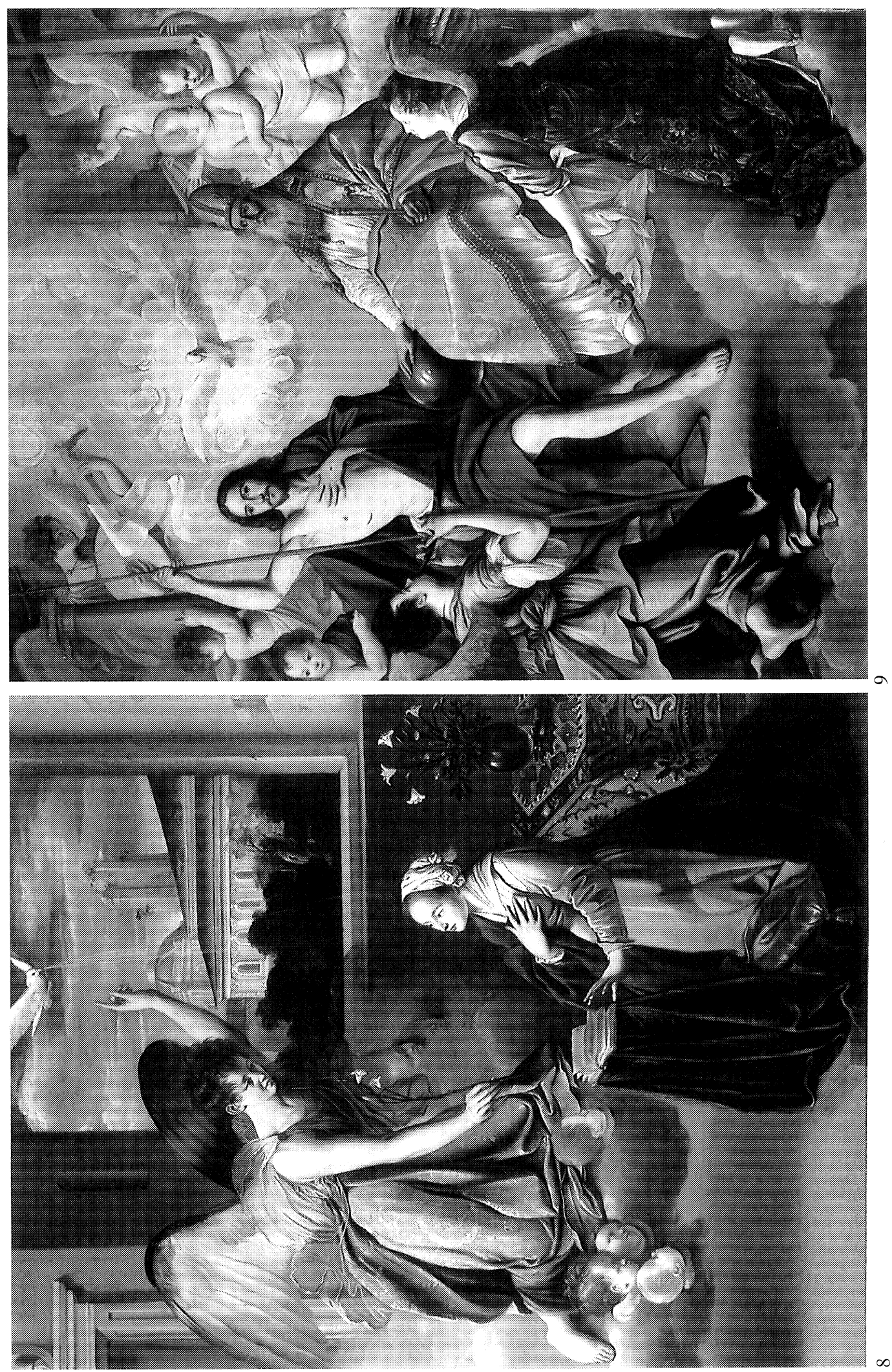

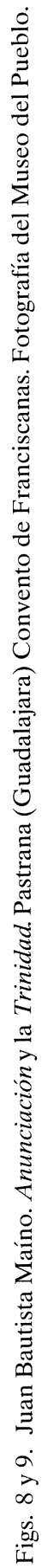


que rodean al Espíritu Santo, parecen anticipar las que en el testero del coro toledano rodeaban la imagen que lo presidía en su origen.

El lienzo del ático, que Junquera llama la Concepción, de modo un tanto equívoco -pues como es sabido, esta denominación se utiliza habitualmente para la Inmaculada Concepción de la Virgen-, debe, con más rigor, denominarse Encarnación que es el modo con que la Contrarreforma trentina prefería referirse a la Anunciación, acentuando en el prodigio la presencia del Verbo, por encima del episodio biográfico mariano. La interpretación que en él da Maíno, es sin duda una de sus más exquisitos logros, por la soberana elegancia de la delicada Virgen, de humilde gesto sorprendido, y la esbelta silueta del ángel que irrumpe en la estancia envuelto en una dorada nube que borra los contornos geométricos de la habitación. El bellísimo jarrón de flores, que se apoya sobre una mesa cubierta de un denso tapete oriental, y el fondo de paisaje que se advierte tras la amplia ventana, con un espeso jardín y, tras él, construcciones de sabor clásico y una torre medieval, completan una de las más delicadas interpretaciones de un tema, tan frecuente y repetido.

Los modelos humanos son los habituales en sus obras. Especialmente la Virgen, de puntiaguda barbilla, boca breve y largas cejas, es la misma de las famosas Adoración de los Pastores y Epifanía del Prado, y el ángel no es difícil reconocerlo en la Fortaleza de los frescos del presbiterio de San Pedro Mártir, y en uno de los ángeles de la Imposición de la casulla a San Ildefonso de colección particular sevillano ${ }^{21}$.

Creo que el retablo ha de ser de fecha próxima a las pinturas de Toledo, y en todo caso, inmediatamente anterior, ya que es posible que después de su profesión como dominico en el convento toledano no se ausentase de él hasta su marcha a Madrid hacia 1620. Si el retablo lo pagó, como indica la inscripción, "Sor Ana de Morales», hubo de haberlo antes de que fuese elegida abadesa en 1617, y antes también de que Maíno pasase a Toledo, donde en 1611 aparece como «residente». Es probable, pues, que pueda haberse pintado hacia 1609-1610. Recuérdese que según los documentos manejados por Junquera, Maíno se hallaba ya en Pastrana, de vuelta de Italia, en enero de 1608. Cierta rigidez, visible en el gran lienzo y una notable fidelidad a los modelos de Saraceni, obligan a situarlo bastante temprano en su actividad, inmediatamente antes de la madurez que ya muestra el retablo de las Cuatro Pascuas toledano.

De otras obras dadas a conocer en los últimos años nada hay que añadir, salvo que la bella Adoración de los Pastores que se pudo ver en Madrid en la exposición De la Edad Media al Romanticismo de la Galería Caylus, en 1993, ha sido adquirida por el Meadows Museum de Dallas, enriqueciendo muy sustancialmente su colección española. El lienzo procedía del Leeds Castle, en cuya guía de 1985 se recogía en la Sala de Banquetes de Enrique VIII, ya con la atribución a Maíno ${ }^{22}$. La obra es sin duda suya y de muy alta calidad, aunque la figura del pastor arrodillado a la derecha resulte un tanto desmañada. Bellísimo es el paisaje crepuscular del fondo, de equilibrada y serena nobleza, y el intenso naturalismo de los accesorios y del soberbio perro de la izquierda que, con el cordero del pastor-moscóforo, y los obligados mula y buey, atestiguan su ya conocida capacidad de animalista.

Otras obras que le han sido atribuidas recientemente por Gianni Papi (una Salomé de colección privada en Lugano, y una Venta de la primogenitura, que el National Westminster Bank ha sacado recientemente a subasta) no creo, como ya he dicho, que puedan ser suyas.

Y para concluir, una observación que cuestiona, una vez más, la fecha del nacimiento del

21 Angulo-Pérez Sánchez, ob. cit., 1969, p. 316, n. ${ }^{\circ}$ 35, lám. 268

22 Véase Julián Gállego en De la Edad Media al Romantícismo, Galería Caylus, Madrid, 1993-94, pp. 84-87. La noticia de la procedencia, así como de una exposición en la National Gallery londinense, como préstamo de la British Rail, Superannuation Fund, la proporciona el citado libro de María Consuelo Boitani, 1995, p. 244, n. ${ }^{\circ} 31$. 
pintor, que creíamos ya resuelta gracias a las investigaciones del Dr. Cortijo Ayuso. Según sus noticias ${ }^{23}$, la verdadera fecha del nacimiento del pintor era 1581 , puesto que el 15 de octubre de ese año se bautizaba un «Juan Bautista» Maíno, mientras que la fecha de 1578 dada a conocer por el padre García Figar en 1958, correspondería a la de un hermano suyo bautizado como simplemente «Juan». Pero sorprende advertir que de unas declaraciones del pintor sobre su edad, se deduce también la fecha de 1578. En 1620, cuando declara en el citado pleito de los doradores dice ser de cuarenta y dos años, lo que da la citada fecha. Todavía podríamos, forzando la lectura, suponer corroborada esa de 1578 si en su declaración en el proceso de la beata Briñas, el año 1638, leemos sesenta años, donde el autor del artículo citado leía setenta. Con la primera lectura tendríamos de nuevo 1578; con la segunda, 1568 , fecha a todas luces imposible, pues el más antiguo de los bautismos de la familia es de 1575 , y sobre todo porque contradice lo dicho por él mismo 18 años antes. Sabida la imprecisión con que se solía declarar la edad en el siglo xviI, no debe sorprender demasiado, pero no deja de sembrar una duda razonable, que, por otra parte, nada afecta al artista y a su obra.

${ }^{23}$ F. Cortijo Ayuso, «El pintor Juan Bautista Maíno y su familia», Wad-al-Hayara, 1978, n.o 5, pp. 285-291. 